\title{
Distribution and abundance patterns of echinoderms in the fjord and channel complex from a subantarctic north Patagonian Ice field, Magellan region
}

\author{
Erika Mutschke ${ }^{1}$, Dieter Gerdes ${ }^{2} \&$ Carlos Ríos $^{1}$ \\ 1. Laboratorio de Hidrobiología, Instituto de la Patagonia, Universidad de Magallanes, Av Bulnes 01855, \\ P.O. Box 113-D. Punta Arenas, Chile; erika.mutschke@umag.cl \\ 2. Alfred Wegener Institut. Helmholtz-Zentrum für Polar und Meeresforschung. Columbusstr. 27570 \\ Bremerhaven, Germany.
}

Received 26-IV-2017. Corrected 15-V-2017. Accepted 25-VI-2017.

\begin{abstract}
The existence of latitudinal marine biodiversity gradients from low to high-southern latitudes is a controversial issue regarding the marine biogeographic division in the Southeastern Pacific. In this region, the Northern Patagonian Icefield is considered a break point for faunistic elements derived from more northern or southern biogeographical realms. However, the division seems to be better defined by distribution patterns and endemism of specific marine taxa. There have been no exhaustive latitudinal benthic inventories compiled along the southern-eastern Pacific Chilean coastline. This study focuses on the spatial distribution variability and relative abundance of the sublittoral echinoderm assemblages and uses them to establish an evaluation of zoogeographic relationship in the Southeastern Pacific and Atlantic Oceans. This is the first time echinoderms have been used for this purpose. A total 3665 echinoderm specimens were collected in two cruises. Within this organism pool, 29 species were distinguished, belonging to the asteroids (17 species), echinoids (6 species), ophiuroids (4 species) and holothurians ( 2 species); crinoids were not found. The dominant species were the asteroid Ctenodiscus procurator, the echinoid Pseudechinus magellanicus, the ophiuroid Ophiuroglypha lymani, and the irregular sea urchin Tripylaster philippii. The spatial distribution patterns for the echinoderm clusters along the study area showed only weak geographical trends. Stations belong in three groups: with influence of glacier processes, influence of waters of the open Pacific Ocean, and a third group of stations without any links to specific locations. Rev. Biol. Trop. 65(Suppl. 1): S60-S72. Epub 2017 November 01.
\end{abstract}

Key words: Patagonian icefield; zoogeography; Magellan region; invertebrates; asteroids.

Biogeographic division of the marine realm in the Southeastern Pacific is a controversial issue as also is the discussion about the existence of latitudinal marine biodiversity gradients from low to high-Antarctic latitudes (Crame, 1999; Gray, 2001, 2002; Arntz, 1999; Arntz, Lovrich, \& Thatje, 2005). At the southern tip of South America there have been several attempts to produce a robust biogeographic zonation scheme based on distribution patterns of different macrofaunistic taxa (Viviani, 1979; Battström \& Johanssen, 1983; Lancellotti \& Vásquez, 1999; Camus, 2001). Camus (2001) resumed 27 biogeographic classifications published so far for the entire Chilean coastline.

Zoogeographically, the region from Chiloé to the southernmost Patagonian seems to be better defined by distribution patterns and endemism of specific marine benthic taxa, as has already been studied for ophiuroids (Dahm, 1999), holothurians (Pawson, 1969), echinoids (Pawson, 1966), asteroids (Codoceo \& Andrade, 1978), molluscs (Valdovinos, Navarrete, \& Marquet, 2003), bryozoan (Moyano, 1982, 1999), nudibranchia (Schrödl, 1999) and sea anemones (Häussermann, 2006). 
The biogeographic patterns in this region are not unique to the region, rather they are the result of complex interactions between heterogeneous local abiotic phenomena and the biology of benthic organisms, their origin tolerance values to environmental parameters, physical characteristics along the Chilean coast (Pantoja, Iriarte, \& Daneri, 2011) and dispersion processes whithin the different taxa of marine invertebrates (Camus, 2001). Geomorphologic glacier formation has influenced the biological history of the region. The presence/absence of massive glacier fronts create distinct local and regional abiotic and biotic differences (Kilian \& Lamy, 2012; Kilian et al., 2013; Ríos, Kilian, \& Mutschke, 2016; Darvill, Stokes, Bentley, Evans, \& Lovell, 2016). Massive glacier advance and retreat has resulted in coastal fragmentation and created different habitat types. Their effects on biodiversity and the isolation of species in these heterogeneous area has not been explored in detail (Camus, 2001, Munilla $\&$ Soler, 2009). No exhaustive latitudinal benthic inventories carried out to date along the southern-eastern Pacific Chilean coastline have been performed so far to help address questions (Fernández et al., 2000; Escribano, Fernández, \& Aranís, 2003).

The fjord and channel complex at the southern tip of South America has been extensively studied several times from 1995 onwards (Sievers, \& Silva, 2006; Mutschke, 2008). It has been found from preliminary investigations that echinoderms are a dominant group, both in number and biomass, within the macrozoobenthos assemblages inhabiting this region (Ríos, Mutschke, Montiel, Gerdes, \& Arntz, 2005; Mutschke, 2006; Ríos, Mutschke, \& Montiel,, 2013). It is not clear yet whether this dominance continues into adjacent northern areas of this complex zone, although in southern parts (Straits of Magellan) concordance in terms of biomass has been found (Mutschke \& Ríos, 2006).

This study focuses on the distribution of echinoderms, especially asteroids, along the Northern Patagonian Icefield. Several authors suggest this area as a break point for faunistic elements derived from more northern or southern biogeographical realms (Viviani, 1979; Battström \& Johanssen, 1983; Lancellotti \& Vásquez, 1999; Camus, 2001). The specific objectives of the study are (a) to describe for the first time the spatial variability and relative abundance of the sublitoral echinoderm assemblages in fjords and channels located along the Northern Patagonian Icefield; and (b) to establish an evaluation of the zoogeographic relationships of echinoderms in the Southeastern Pacific and Atlantic Oceans, focusing on data on asteroids distribution.

\section{MATERIALS AND METHODS}

Study area. The Pacific coast of the Southern tip of South America is structured by a complex system of fjords and channels with distinct local and regional abiotic -and presumably biotic- differences determined by the presence/absence of massive glacier fronts, which are part of the largest temperate ice masses in the southern hemisphere, the Northern and Southern Patagonian Icefields. (Hulton, Purves, McCulloch, Sugden, \& Bentley, 2002; Kilian \& Lamy, 2012; Kilian et al., 2013; Darvill, Stokes, Bentley, Evans, \& Lovell, 2016). The thermal and saline structures of the interior waters in front of these icefields are affected by a peculiar topography (Pinochet \& Salinas, 1996; Kilian et al., 2007). They receive inputs of different water masses from the adjacent Pacific Ocean (Palma \& Silva, 2004) through numerous connecting channels. These waters mix in the interior zone with freshwater from precipitation, river flow, and meltwater from mountain glaciers, leading to a typically twolayered structure of the water column with higher temperature and lower salinity in the upper layer and a more stable, cooler deeper layer with higher salinity. In winter, the riverine freshwater input is cooler thus producing thermal inversion in the surface water layer. Towards the open Pacific shelf appears a distinct east/west gradient appears with an increase in salinity and temperature (Pinochet \& Salinas, 1996). As a result, the waters along 
both icefields are a very complex system creating highly heterogeneous and particular abiotic and biotic habitat features for benthic organisms.

Samples analyzed in this article were collected at sites located in the warmer northern ice sheet domain where particularly rapid ice wastage occurs (Fig. 1).

Sampling procedures. Samples were collected during the CIMAR/FIORDO 7 (July 2001) and CIMAR/FIORDO 8 (July 2002) cruises of the Chilean Comite Oceanográfico Nacional (CONA) aboard the R/V Vidal Gormaz in the Austral winter season. 46 stations were sampled along fjords and channels

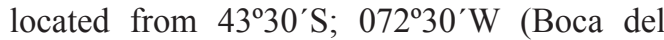
Guafo) to $46^{\circ} 30^{\prime} \mathrm{S} ; 75^{\circ} \mathrm{W}$ (Golfo de Penas; Fig.1). The sampling locations, depths, and geographical coordinates are summarized in Table 1 for both cruises.

Trawl gear used was a modified Agassiztype trawl (AGT; mouth width $1.5 \mathrm{~m}$ fitted with a $10 \mathrm{~mm}$ net) deployed once per location. From the moment of contact with the bottom, the AGT was towed at a speed of about 1.5 knots for $15 \mathrm{~min}$. From each sample obtained per site and deployment, a 51 sub-sample was separated for later analyses of sediments and benthos. Sub-samples were sieved on board through a $1 \mathrm{~mm}$ mesh and all echinoderms were separated out. Sorted specimens were preserved in a $4 \%$ hexamethylenetetramine buffered seawater formalin solution for later identification in the laboratory.

Identification of species was based mainly on the publications of Bernasconi $(1953 ; 1962$; 1963; 1964), Clark (1920), Clark \& Downey

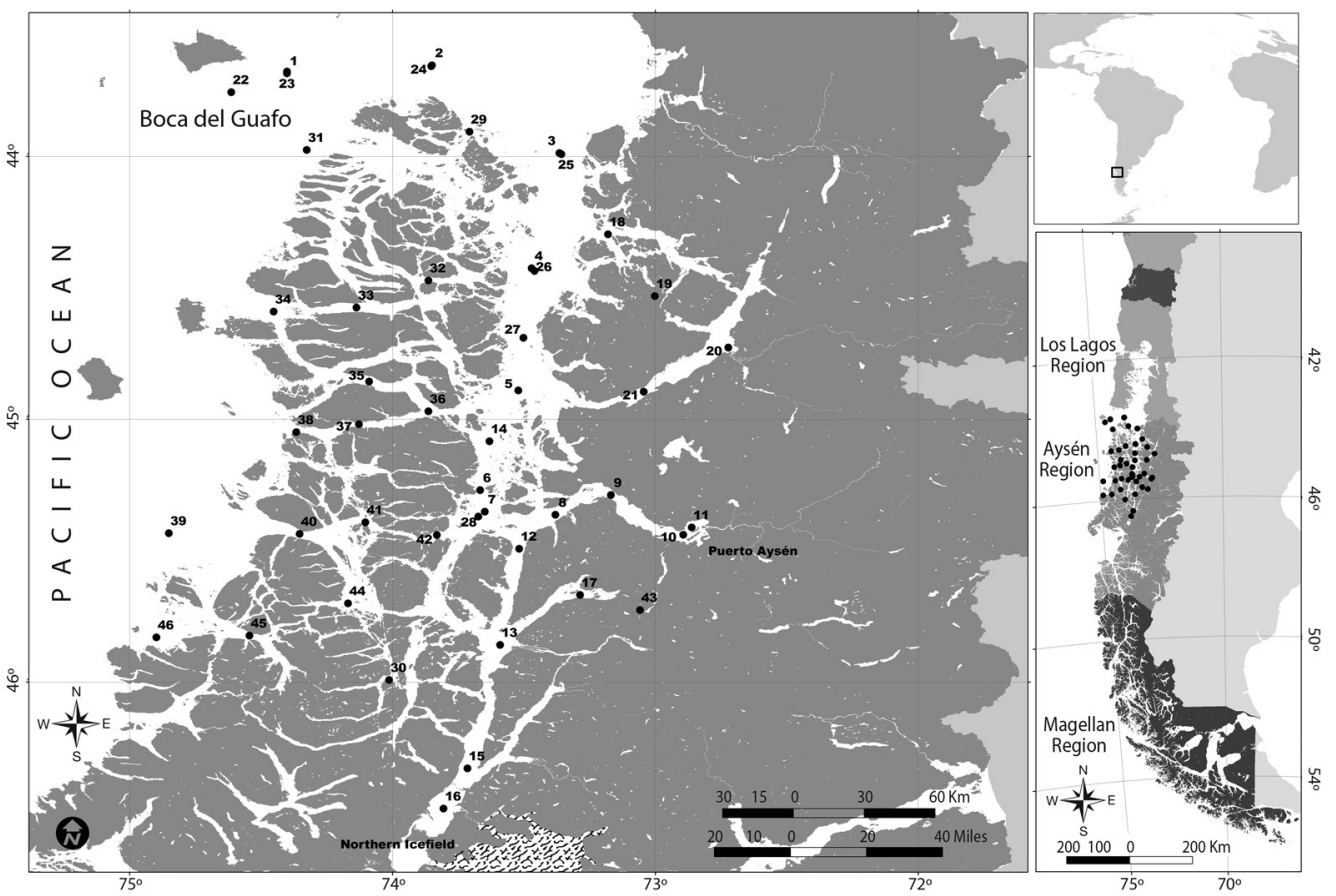

Fig. 1. Study area and location of 46 sampling sites in the southern fjord and channels complex, Chilean Patagonia sampled in the CIMAR Fiordos Cruise 7 and 8.

Fig. 1. Área de estudio y localización de los 46 sitios de muestreo, considerados en el Crucerp Fiordos CIMAR 7 y 8 , los fiordos del sur y los complejos de canales. 
TABLE 1

General characteristics of the 46 sampling sites considered in the CIMAR Fiordos Cruise 7 and 8 , to the southern fjord and channels complex, Magellanic región, Chile

\section{CUADRO 1}

Características generales de 46 sitios de muestreo considerados en los Cruceros Fiordos CIMAR 7 y 8 , de los fiordos del sur y el complejo de canales, región Magallánica, Chile

\begin{tabular}{|c|c|c|c|c|c|}
\hline Station $N^{\circ}$ & Latitude (S) & Longitude (W) & Depth (m) & Site name & Sampling date \\
\hline 1 & $43^{\circ} 40.99$ & $74^{\circ} 24.10$ & 202 & Boca del Guafo & 08/07/2001 \\
\hline 2 & $43^{\circ} 39.18$ & $73^{\circ} 50.95$ & 170 & Boca del Guafo & 08/07/2001 \\
\hline 3 & $43^{\circ} 59.19$ & $73^{\circ} 21.87$ & 179 & Canal Moraleda & 09/07/2001 \\
\hline 4 & $44^{\circ} 25.50$ & $73^{\circ} 28.20$ & 410 & Canal Moraleda & 09/07/2001 \\
\hline 5 & $44^{\circ} 53.38$ & $73^{\circ} 31.25$ & 198 & Canal Moraleda & 09/07/2001 \\
\hline 6 & $45^{\circ} 16.17$ & $73^{\circ} 39.98$ & 64 & Canal Moraleda & 09/07/2001 \\
\hline 7 & $45^{\circ} 21.10$ & $73^{\circ} 38.88$ & 156 & Canal Moraleda & 09/07/2001 \\
\hline 8 & $45^{\circ} 21.80$ & $73^{\circ} 22.78$ & 248 & Seno Aysén & 09/07/2001 \\
\hline 9 & $45^{\circ} 17.28$ & $73^{\circ} 10.13$ & 339 & Seno Aysén & $10 / 07 / 2001$ \\
\hline 10 & $45^{\circ} 26.36$ & $72^{\circ} 53.56$ & 174 & Seno Aysén & $10 / 07 / 2001$ \\
\hline 11 & $45^{\circ} 24.69$ & $72^{\circ} 51.64$ & 156 & Seno Aysén & $11 / 07 / 2001$ \\
\hline 12 & $45^{\circ} 29.56$ & $73^{\circ} 31.03$ & 304 & Canal Costa & $10 / 07 / 2001$ \\
\hline 13 & $45^{\circ} 51.50$ & $73^{\circ} 35.41$ & 110 & Seno Elefantes & $13 / 07 / 2001$ \\
\hline 14 & $45^{\circ} 05.01$ & $73^{\circ} 37.82$ & 56 & Seno Elefantes & $14 / 07 / 2001$ \\
\hline 15 & $46^{\circ} 19.69$ & $73^{\circ} 42.88$ & 20 & Seno Elefantes & $14 / 07 / 2001$ \\
\hline 16 & $46^{\circ} 28.88$ & $73^{\circ} 48.32$ & 116 & Seno Elefantes & $15 / 07 / 2001$ \\
\hline 17 & $45^{\circ} 40.07$ & $73^{\circ} 17.17$ & 270 & Seno Quitralco & $17 / 07 / 2001$ \\
\hline 18 & $44^{\circ} 17.76$ & $73^{\circ} 10.78$ & 444 & Canal Jacaf & $19 / 07 / 2001$ \\
\hline 19 & $44^{\circ} 31.85$ & $72^{\circ} 60.09$ & 258 & Seno Ventisquero & $19 / 07 / 2001$ \\
\hline 20 & $44^{\circ} 43.59$ & 72.43 .30 & 196 & Canal Puyuhuapi & $18 / 07 / 2001$ \\
\hline 21 & $44^{\circ} 53.69$ & 73.02 .60 & 238 & Canal Puyuhuapi & $17 / 07 / 2001$ \\
\hline 22 & $43^{\circ} 45.29$ & $74^{\circ} 36.78$ & 240 & Boca del Guafo & $06 / 07 / 2002$ \\
\hline 23 & $43^{\circ} 40.57$ & $74^{\circ} 24.07$ & 200 & Boca del Guafo & 06/07/2002 \\
\hline 24 & $43^{\circ} 39.36$ & $73^{\circ} 51.11$ & 189 & Boca del Guafo & 06/07/2002 \\
\hline 25 & $43^{\circ} 59.43$ & $73^{\circ} 21.43$ & 170 & Canal Moraleda & 06/07/2002 \\
\hline 26 & $44^{\circ} 26.11$ & $73^{\circ} 27.54$ & 380 & Canal Moraleda & 07/07/2002 \\
\hline 27 & $44^{\circ} 41.37$ & $73^{\circ} 30.10$ & 322 & Canal Moraleda & 07/07/2002 \\
\hline 28 & $45^{\circ} 22.21$ & $73^{\circ} 40.40$ & 87 & Canal Moraleda & 07/07/2002 \\
\hline 29 & $43^{\circ} 54.33$ & $73^{\circ} 42.41$ & 58 & Canal Leucayec & $20 / 07 / 2002$ \\
\hline 30 & $45^{\circ} 59.50$ & $74^{\circ} 00.77$ & 203 & Canal Taumapu & $20 / 07 / 2002$ \\
\hline 31 & $43^{\circ} 58.50$ & $74^{\circ} 19.58$ & 190 & Canal Taumapu & $20 / 07 / 2002$ \\
\hline 32 & $44^{\circ} 28.29$ & $73^{\circ} 51.79$ & 132 & Canal Baeza & $17 / 07 / 2002$ \\
\hline 33 & $44^{\circ} 34.50$ & $74^{\circ} 08.19$ & 200 & Canal King & $17 / 07 / 2002$ \\
\hline 34 & $44^{\circ} 35.40$ & $74^{\circ} 27.13$ & 156 & Canal King & $16 / 07 / 2002$ \\
\hline 35 & $44^{\circ} 51.36$ & $74^{\circ} 05.34$ & 160 & Canal Goñy & $16 / 07 / 2002$ \\
\hline 36 & $44^{\circ} 58.17$ & $73^{\circ} 51.79$ & 180 & Canal Ninaulac & $11 / 07 / 2002$ \\
\hline 37 & $45^{\circ} 01.08$ & $74^{\circ} 07.66$ & 274 & Canal Ninaulac & $11 / 07 / 2002$ \\
\hline 38 & $45^{\circ} 02.90$ & $74^{\circ} 21.94$ & 154 & Canal Ninaulac & $12 / 07 / 2002$ \\
\hline 39 & $45^{\circ} 26.00$ & $74^{\circ} 51.03$ & 90 & Canal Darwin & $10 / 07 / 2002$ \\
\hline 40 & $45^{\circ} 26.16$ & $74^{\circ} 21.18$ & 224 & Canal Darwin & $10 / 07 / 2002$ \\
\hline 41 & $45^{\circ} 23.49$ & $74^{\circ} 06.20$ & 170 & Canal Darwin & $10 / 07 / 2002$ \\
\hline 42 & $45^{\circ} 26.38$ & $73^{\circ} 49.85$ & 242 & Canal Darwin & $10 / 07 / 2002$ \\
\hline 43 & $45^{\circ} 43.55$ & $73^{\circ} 03.48$ & 86 & Canal Chacabuco & 08/07/2002 \\
\hline 44 & $45^{\circ} 42.00$ & $74^{\circ} 10.13$ & 61 & Canal Chacabuco & 08/07/2002 \\
\hline 45 & $45^{\circ} 49.34$ & $74^{\circ} 32.65$ & 210 & Canal Pulluche & 08/07/2002 \\
\hline 46 & $45^{\circ} 49.76$ & $74^{\circ} 53.89$ & 82 & Bahía Anna Pink & $09 / 07 / 2002$ \\
\hline
\end{tabular}


(1992), Castillo (1968), Larraín (1975), Madsen (1956) and Pawson (1969).

Data analysis. Multivariate statistics were applied to perform community analyses using the software package PRIMER v.6 (Clarke \& Gorley 2006). Statistical analyses were based on presence/absence data of echinoderm species at each station. Agassiz trawl not allow a quantitative estimation of density. We prefer the presence/ absence transformation for a proper comparison between sampling station. The similarity profile test (SIMPROF) routine was used to test the internal group structure in the full set of samples, i.e. to demonstrate the statistical significance of differences among the groups defined by the cluster analysis. Dominant species in each group were determined considering only species with more than $4 \%$ of contribution to the relative abundance in each group. Multidimensional scaling (MDS) and analyses of similarity in, and dissimilarity between groups were performed using the Bray-Curtis Index. The dominance of species was corroborated with the routine SIMPER from PRIMER, which calculates similarities within groups and dissimilarities between groups resulting from cluster and multidimensional scaling.

\section{RESULTS}

Species numbers and composition. A total 3665 echinoderm specimens were collected from these two cruises. The numbers of species collected per station varied between 982 . There was a weak trend of higher collection numbers at stations inside the complex channel system. Most specimens were collected at St. 9 (982) in Seno Aysén at St. 19 (662) in Seno Ventisquero and at St. 8 (423) in the western entrance of Seno Aysén. Almost three quarters (73\%) of the entire echinoderm specimens were collected at just 7 stations, and less than 10 specimens were found at 19 stations in the subsample trawled material. The most diverse echinoderm inventory came from St. 36, 37, 40 and 41 , where $\geq 10$ species were collected; at 4 stations 6 to 9 species were found and $\leq 5$ were collected at the other 37 stations. Within this organism pool 29 species of echinoderm were distinguished - asteroids (17 species, 59\%), echinoids (6 species, 21\%), ophiuroids (4 species, 13\%) and holothurians (2 species, 7\%); crinoids were not found (Fig. 2). The most dominant species collected were the asteroid Ctenodiscus procurator (1332 individuals), the echinoids Pseudechinus magellanicus (1041 specimens) and T. philippii (279 specimens), and the ophiuroid Ophiuroglypha lymani (314 specimens), between them accounting for almost $81 \%$ of the entire echinoderms collected. Ten other species were collected in numbers between 10 and 114, 13 species were found with $<10$ specimens, two of them, Cheiraster (Luidiaster) planeta and D. singularis were only found in a single specimen.

The most frequently found species $P$. magellanicus, T. phillipii, Cosmasterias lurida, and Arbacia dufresni, occurred at 22, 17, and 15 stations, respectively. These species were part of a group of 7 seastars and echinoids, which were collected at $\geq 10$ stations. Twelve species were collected at 4 to 6 stations and 10 species were found at less than three stations.

Species groups, composition and distribution patterns within the study area. The SIMPROF procedure of the similarity matrix based on presence/absence data identified three main clusters (group $a=14$ stn; group $b=8$ $\mathrm{stn}$; group $\mathrm{c}=22 \mathrm{stn}$ ) and these groups were also confirmed by multi-dimensional scaling (Fig. 2). Two single stations (St. 25 at Canal Moraleda and St. 46 at Bahía Anna Pink) were separated from the main groups. Both had only one echinoderm species and differed in more than $98 \%$ from the general conglomerates defined by cluster and nMDS analyses. The SIMPER analysis showed relatively low average 'within-group similarities' for these clusters (Table 3). The highest value was for group b with $50.8 \%$; Porania antarctica, A. dufresni and $C$. lurida were the main contributors to this similarity. Next was group c followed with $46.2 \%$ within group similarity, mainly due to 


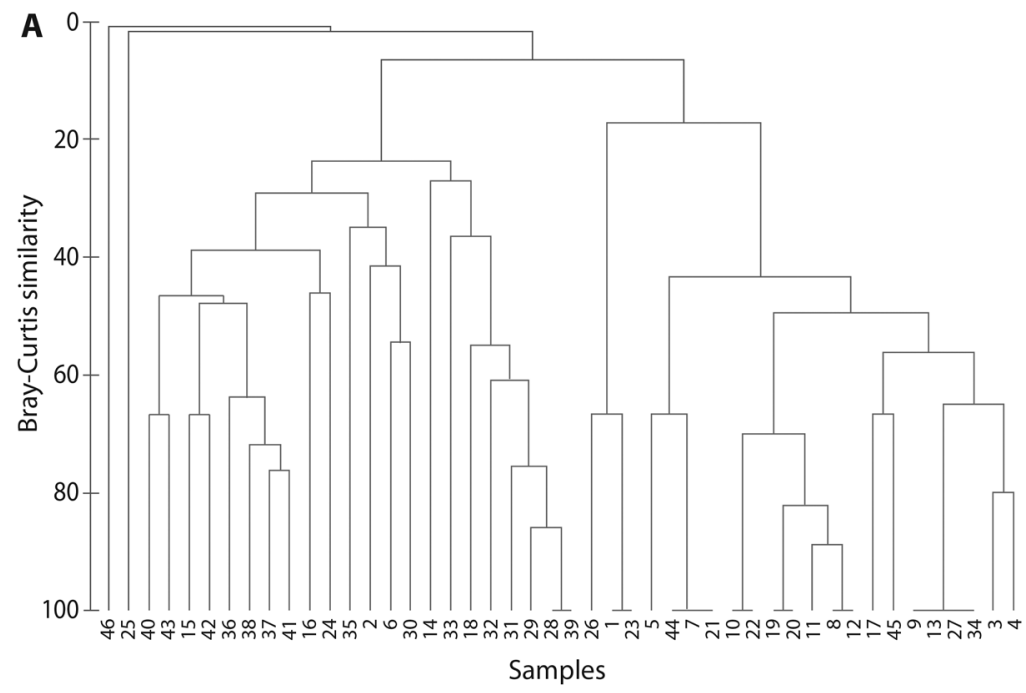

B

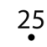

2D Stress: 0.07

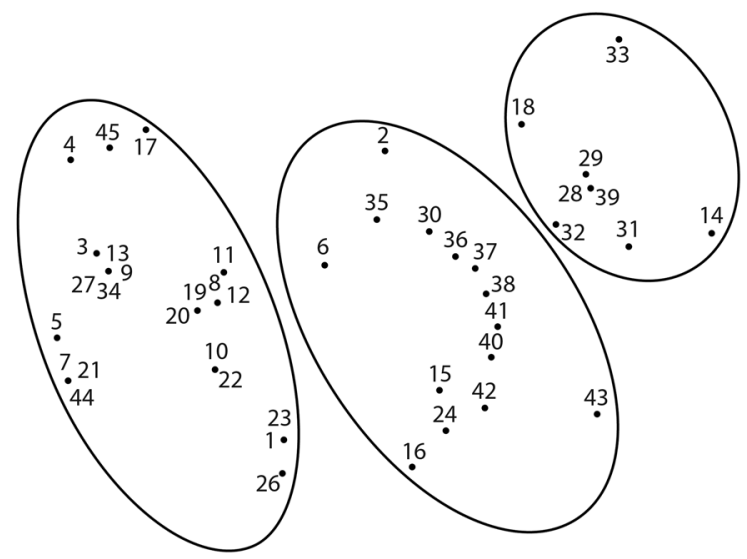

46

Fig. 2. A) Cluster analysis and B) multidimensional scaling ordination for presence/absence transformed echinoderm species data.

Fig. 2. A). Análisis cluster y B) Análisis de escalamiento multidimensional para los datos transformados de presencia / ausencia de las especies de equinodermos.

the contribution of $T$. philippii, $C$. procurator and $P$. magellanicus. Lowest 'within-group similarity' resulted for group a $(39.1 \%)$ due to the presence of $P$. magellanicus, Asterina fimbriata, and C. lurida.

The average 'between-group dissimilarities' varied between 76.3\% (groups a and b), and $99.5 \%$ (c and b) with an intermediate value of $89.9 \%$ dissimilarity between groups c and a. The spatial distribution patterns for the echinoderm clusters showed only weak trends. Sampling stations forming the group "c" were distributed mainly -but not exclusively- in those areas more directly influenced by the glacier processes. Cluster " $b$ " corresponds to sampling stations more related to the direct influence of open waters of the Pacific Ocean, whereas stations forming cluster "a" did not show any preference to specific locations. 


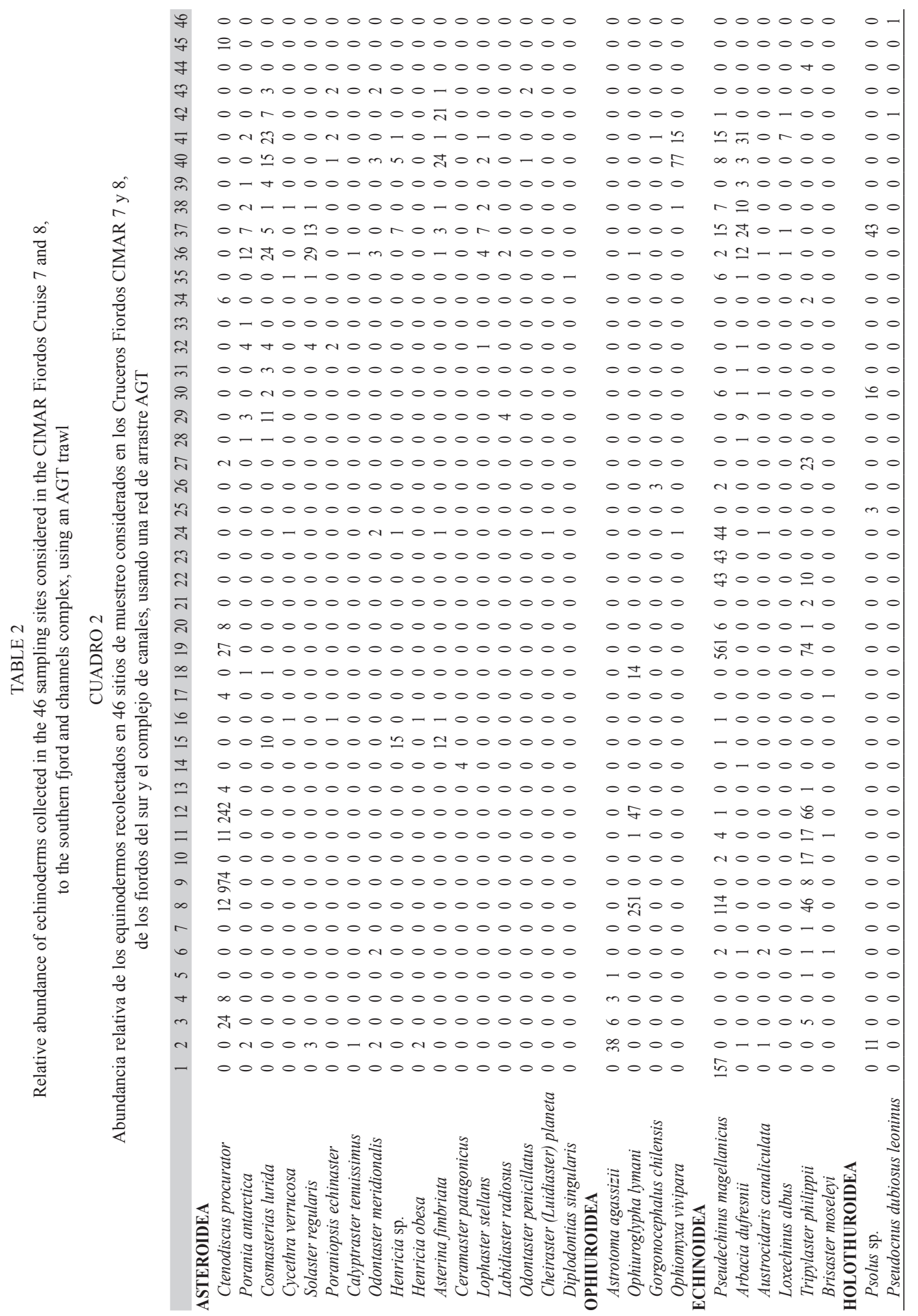


TABLE 3

Percentage contribution of echinoderms species to the Bray-Curtis similarity and dissimilarity values within and between groups of sites as defined by the cluster and nMDS analysis

CUADRO 3

Porcentaje de contribución de las species de equinodermos con los valores de similitud y disimilitud de Bray-Curtis según las agrupaciones de sitios definidas en los análisis de nMDS y cluster

\begin{tabular}{|c|c|c|c|c|c|}
\hline & Av.Abund & Av.Sim & $\mathrm{Sim} / \mathrm{SD}$ & Contrib\% & Cum. $\%$ \\
\hline \multicolumn{6}{|c|}{ Group a Average similarity: 39.12} \\
\hline Pseudechinus magellanicus & 0.86 & 10.23 & 1.44 & 26.15 & 26.15 \\
\hline Asterina fimbriata & 0.71 & 6.61 & 0.92 & 16.89 & 43.04 \\
\hline Cosmasterias lurida & 0.64 & 5.32 & 0.75 & 13.60 & 56.64 \\
\hline \multicolumn{6}{|c|}{ Group b Average similarity: 50.83} \\
\hline Porania antarctica & 0.75 & 17.53 & 0.96 & 34.50 & 34.50 \\
\hline Arbacia dufresnii & 0.75 & 17.20 & 0.99 & 33.84 & 68.33 \\
\hline Cosmasterias lurida & 0.75 & 16.10 & 1.00 & 31.67 & 100.00 \\
\hline \multicolumn{6}{|c|}{ Group c Average similarity: 46.24} \\
\hline Tripylaster philippii & 0.73 & 23.65 & 0.93 & 51.14 & 51.14 \\
\hline Ctenodiscus procurator & 0.59 & 13.51 & 0.67 & 29.22 & 80.36 \\
\hline Pseudechinus magellanicus & 0.45 & 8.09 & 0.45 & 17.50 & 97.87 \\
\hline
\end{tabular}

Groups a \& b Average dissimilarity $=76.32$

\begin{tabular}{lcccccc}
\multicolumn{1}{c}{ Species } & $\begin{array}{c}\text { Av.Abund } \\
\text { Group a }\end{array}$ & $\begin{array}{c}\text { Av.Abund } \\
\text { Group b }\end{array}$ & Av.Diss & Diss/SD & Contrib\% & Cum.\% \\
Pseudechinus magellanicus & 0.86 & 0.00 & 8.89 & 1.89 & 11.64 & 11.64 \\
Asterina fimbriata & 0.71 & 0.00 & 7.16 & 1.34 & 9.38 & 21.02 \\
Porania antarctica & 0.36 & 0.75 & 6.29 & 1.07 & 8.24 & 29.26 \\
Arbacia dufresnii & 0.64 & 0.75 & 4.84 & 0.82 & 6.34 & 35.60 \\
Cosmasterias lurida & 0.64 & 0.75 & 4.67 & 0.81 & 6.11 & 41.72 \\
Odontaster meridionalis & 0.43 & 0.00 & 4.00 & 0.81 & 5.24 & 46.96 \\
Solaster regularis & 0.36 & 0.13 & 3.49 & 0.76 & 4.57 & 51.53
\end{tabular}

Groups c \& a Average dissimilarity $=89.94$

$\begin{array}{lcccccc} & \text { Group c } & \text { Group a } & & & & \\ \text { Asterina fimbriata } & 0.00 & 0.71 & 7.78 & 1.34 & 8.65 & 8.65 \\ \text { Tripylaster philippii } & 0.73 & 0.07 & 7.65 & 1.31 & 8.50 & 17.16 \\ \text { Cosmasterias lurida } & 0.00 & 0.64 & 7.08 & 1.16 & 7.87 & 25.02 \\ \text { Arbacia dufresnii } & 0.00 & 0.64 & 6.40 & 1.20 & 7.12 & 32.14 \\ \text { Ctenodiscus procurator } & 0.59 & 0.00 & 6.31 & 1.09 & 7.01 & 39.16 \\ \text { Pseudechinus magellanicus } & 0.45 & 0.86 & 6.23 & 0.97 & 6.93 & 46.09 \\ \text { Odontaster meridionalis } & 0.00 & 0.43 & 4.32 & 0.81 & 4.80 & 50.89\end{array}$

Groups c \& b Average dissimilarity $=99.53$

\begin{tabular}{lcccccc} 
& Group c & Group b & & & & \\
Porania antarctica & 0.00 & 0.75 & 15.49 & 1.33 & 15.57 & 15.57 \\
Tripylaster philippii & 0.73 & 0.00 & 15.04 & 1.33 & 15.11 & 30.68 \\
Arbacia dufresnii & 0.00 & 0.75 & 14.98 & 1.47 & 15.05 & 45.72 \\
Cosmasterias lurida & 0.00 & 0.75 & 14.32 & 1.50 & 14.38 & 60.11 \\
\hline
\end{tabular}




\section{DISCUSSION}

Several studies along the Chilean Pacific coastline (Challenger Expedition in 1872-1876, Sladen, 1889; Lund University Expedition 1948-49, Madsen, 1956) concluded that the distribution of macrobenthic invertebrates along the Chilean coastline is discontinuous (Viviani, 1979; Brattström \& Johanssen, 1983; Camus, 2001). Most studies so far have proposed two basic biogeographical provinces/ regions along Chile: the northern warm-temperate Peruvian Province and the southern cold-water Magellanic Province. The border at about $42^{\circ} \mathrm{S}$ between these provinces coincides conveniently with abrupt changes in topography, climate and hydrography (Ahumada, Pinto, \& Camus, 2000).

Since 1980, there has been intensive aquaculture along this coast (salmon) and extensive fishing of crustaceans, molluscs and echinoderms. Hence studies on the marine benthic fauna in the fjords and channel ecosystems have become more important. Recently, extensive efforts have been made to sample the macrobenthic communities in this part of South America, vast areas of which are among the poorest studied regions worldwide. The first main expedition was with the "Victor Hensen" Magellan Campaign in 1994 (Arntz, 1999) and followed by several Chilean expeditions under the umbrella of the CIMAR Program (Mutschke, 2008; Sivers \& Silva, 2006). Through these knowledge about the Magellan benthos has greatly increased, especially with respect to benthic species inventories (bryozoans, echinoderms, polychaetes, decapods, molluscs), although still being far from complete.

This study as part of the CIMAR Fiordo Programms 7 and 8 is based on a collection of samples from 46 stations in an area of about $6,000 \mathrm{~km}^{2}$ along the Southern and Northern Patagonian Icefields, some hundred miles south of the border between the two biogeographical provinces. This region has to be regarded as an ecologically young and complex system, with highly heterogeneous and particular habitat features for the benthos.
This complex heterogeneity might explain the distribution pattern related to the three groups found from the cluster analysis, although 'within-group average similarities' where rather low.

A total 29 echinoderm species were identified with a clear predominance of the Class Asteroidea, followed by the Classes Echinoidea, Ophiuroidea and Holothuroidea. This class abundance order seems to be a common characteristic in macrobenthic communities living in Chilean southernmost fjords and channels. Perez-Ruzafa et al. (2013) described the echinoderms in the marine communities around the cone of South America as one of the most conspicuous phylum. According to these authors, 45 asteroid species are described from the Magellan waters, constituting by far the most diverse echinoderm group as also holds true for Argentine waters with 52 species and for Antarctica with 295 species. All species found in this study were also found by Pérez-Ruzafa et al. (2013) for the Magellan region. Nineteen of these are also described for the Argentine -Atlantic sector, 6 of these species ( $P$. antarctica, Cycethra verrucosa, Odontaster penicillatus, Astrotoma agassizii, O. lymani, Gorgonocephalus chilensis) occur in Antarctic waters (Griffiths, Danis, \& Clarke, 2011) and five of these species (P. antarctica, C.verrucosa, L. stellans, O. penicillatus, $G$. chilensis) were described in the Temperate Peruvian Province (Mutschke, Ríos, Aldea, Montiel, \& Silva, 2016).

Palma et al. (2005) found several polychaete and echinoderm species, which also occurred in Antarctic and sub-Antarctic waters further south. The authors hypothesized that the Antarctic Intermediate Water (AAIW), which stretches along the Chilean continental margin in 400 to $1200 \mathrm{~m}$ deep, transports these species to the northern latitudes. The widespread distribution patterns of many echinoderms in waters at the southern tip of South America agrees with the results of other specific studies such as those of Lancellotti \& Vásquez (1999), Larraín, Mutschke, Riveros, \& Solar, (1999), Penchaszadeh, Bigatti, \& Miloslavich (2004), Ríos, Mutschke, Montiel, Gerdes, 
\& Arntz, (2005), López-Gappa \& Sueiro (2007), González-Wevar et al. (2016), probably mirroring abilities of these invertebrates to cope with the environmental heterogeneity in this hydrographic and ecological complex fjord and channel system. Examples of these echinoderms are G. chilensis and A. agassizii, species that inhabit the Atlantic and Pacific coastlines of South America as well as in Antarctic waters (Hunter \& Halanych, 2008).

The results show a distribution pattern among the stations in reference to the species that characterize them, both qualitatively and quantitatively (Fig. 3). Higher abundances $T$. philippii of C. procurator, and P. magellanicus were found in fjords that form Aysén and Puyuhuapi Sounds- areas with the lowest species richness. This group of species was representative of the group c stations characterized by low temperatures and high presence of clay on the bottom and in the water column, caused by melting of glaciers in the main fjords. The group b stations, characterized by $P$. antarctica, A. dufresnii and C. lurida, was related to sites where there was a higher oceanic influence. On the other hand, Cosmasterias lurida and P. magellanicus (representative of group a stations) were mainly distributed in the channels area, with a higher dispersion of the asteroid and an increment of uniformity that is reflected in a higher number of species and a lower abundance of each one of them. Other studies have suggested that oligotrophic waters (nutrient - poor) and a high discharge of sediments limits richness and abundance in the fjords and channel's benthic ecosystems during the aestival period (Silva \& Prego, 2002). However, there are seasonal fluctuations that have not been studied and which might better explain the trends observed in the marine ecosystems, especially those related to areas that are near the South Ice Fields (Ríos, Mutschke, Montiel, Gerdes, \& Arntz, 2005). The sampling period of the present work was developed in winter season when sedimentation caused by the glaciers melting is lower than in the aestival season. This fact might mean that the communities present in these areas develop in a better
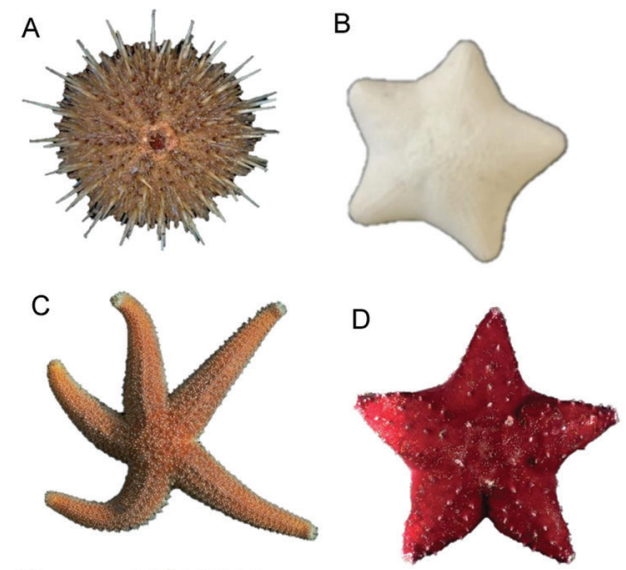

$\mathrm{E}$
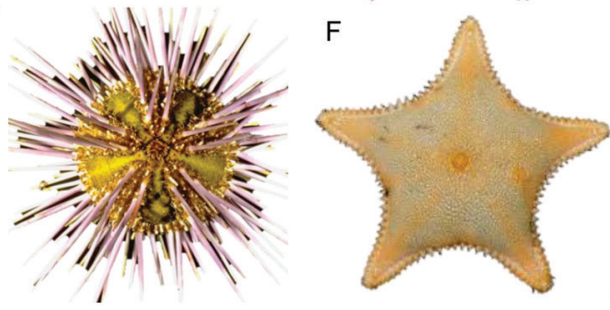

G
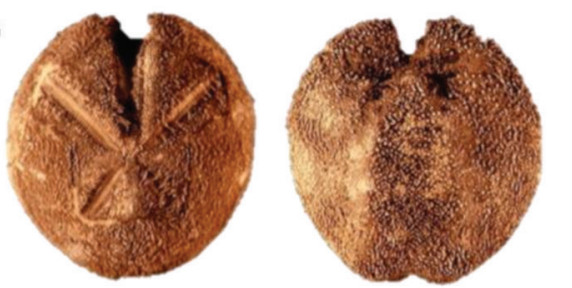

Fig. 3. The most common species composition collected at 46 stations in the Aysén region in July 2001 and 2002. A) Pseudechinus magellanicus; B) Asterina fimbriata; C) Cosmasterias lurida; D) Porania antárctica; E) Arbacia dufresnii, F) Ctenodiscus procurator; G) Trypilaster philippii.

Fig 3. Composición de especies más comunes recolectadas en las 46 estaciones en la región de Aysén en Julio 2001 y 2002. A) Pseudechinus magellanicus; B) Asterina fimbriata; C) Cosmasterias lurida; D) Porania antárctica; E) Arbacia dufresnii, F) Ctenodiscus procurator; G) Trypilaster philippii.

way when the main restriction of the benthic communities in these environments decreases and this would explain the high abundance of the species found.

The most recent studies in this area (Ríos, Mutschke, Montiel, Gerdes, \& Arntz, 2005, Ríos, Mutschke, \& Montiel, 2013) do not cover eventual changes in the faunistic composition 
along longitudinal gradients from inland areas of channels and fjords towards the exposed coast, they have only evaluated latitudinal gradients. From other studies, three phytoplanktonic groups have been differentiated according to their species characteristics (Avaria, Cáceres, $\&$ Muñoz, 2004) that agree with the geographic and oceanographic differences related to the stations groups a and b in this study. According to Avaria, Cáceres, \& Muñoz (2004), a zone of inland channels corresponding to the stations located in the interior area of fjords and sounds, a zone of exterior channels grouped (both corresponding to the group of stations b) and a zone of oceanic influence, (concordant with the group of stations a), are recognized.

Further studies, to describe the distributional patterns of other benthic marine invertebrates in this highly complex system are necessary to improve our understanding of the processes driving the ecology and zoogeography from this isolated, heterogeneous and pristine area.

\section{ACKNOWLEDGEMENTS}

We thank Daniel W. Antunez for providing the map for Figure 1. We want to express our gratitude to the crew of AGOR Vidal Gormaz from the Chilean Navy during the sampling period. Field and laboratory work reported in this manuscript were possible thanks to a grant by the Comite Oceanográfico Nacional of Chile and the Universidad de Magallanes. This paper benefitted greatly from the detailed and considered comments, criticism and advice of three anonymous reviewers. Special thank to Jim McAdam for the English improve.

\section{RESUMEN}

La existencia de un gradiente latitudinal de biodiversidad marina de bajas a altas latitudes es un aspecto controversial de acuerdo a la división biogeográfica marina en el Pacífico suroriental. En esta región, los campos Patagónicos de hielo Norte han sido considerados un punto de quiebre para los elementos faunísticos derivados de reinos biogeográficos más al norte o más al sur. Sin embargo, las divisiones parecen estar mejor definidas por patrones de distribución y de endemismo de taxones marinos específicos. No ha habido un inventario exhaustivo del bentos a lo largo de la línea de costa del Pacífico sureste de Chile. Este estudio se enfoca en la variabilidad de la distribución espacial y en la abundancia relativa del ensamble de equinodermos sublitorales, aspectos que se utilizan para establecer una evaluación de las relaciones zoogeográficas en los océanos Pacífico sureste y Atlántico. Esta es la primera vez que los equinodermos han sido utilizados para este propósito. Un total de 3665 especímenes de equinodermos fueron colectados en dos cruceros. Se identificaron 29 especies de asteroideos (17 especies), equinoideos (seis especies), ofiuroideos (cuatro especies) y holoturoideos (dos especies); no se encontraron crinoideos. Las especies dominantes fueron los asteroideos Ctenodiscus procurator,el equinoideo Pseudechinus magellanicus, el ofiuroideo Ophiuroglypha lymani, y el erizo de mar irregular Tripylaster philippii. Los patrones de distribución espacial para las agrupaciones a lo largo del área de estudio mostraron solo tendencias geográficas débiles. Las estaciones pertenecieron a tres agrupaciones: con influencia de procesos glaciares, influencia de aguas abiertas del Océano Pacífico, y un tercer grupo de estaciones sin ninguna conexión con localidades específicas.

Palabras clave: Campo de hielo patagónico; zoogeografía; región de Magallanes; invertebrados; asteroideos.

\section{REFERENCES}

Ahumada, R. B, Pinto, L. A. \& Camus, P. A. (2000). The Chilean coast, in: Sheppard, C.R.C. (Ed.) Seas at the millennium: an environmental evaluation: 1. Regional chapters: Europe, The Americas and West Africa. pp. 699-717.

Arntz, W. E. (1999). Magellan-Antarctic: Ecosystems that drifted apart. Summary Review. Scientia Marina, 63(S1), 503-511.

Arntz, W. E., Lovrich, G. A. \& Thatje, S. (2005). The Magellan-Antarctic connection: links and frontiers at high southern latitudes (Proceedings of the Second International IBMANT Conference, CADIC, Ushuaia, Argentina, 19-24 Oct 2003). Scientia Marina, 69 (S2), 1-374.

Avaria, S., Cáceres, C. \& Muñoz, P. (2004). Distribución del microfitoplancton marino entre el golfo Corcovado y el estero Elefantes en la primavera de 1998 y en el verano de1999 (Crucero Cimar-4 Fiordos). Ciencia y Tecnología del Mar, 27, 17-47.

Bernasconi, I. (1953). Monografía de los equinoideos argentinos. Anales Museo Historia Natural Montevideo, (2 ${ }^{\text {a }}$ Ser) 6(2), 1-58.

Bernasconi, I. (1962). Asteroideos argentinos. III. Familia Odontasteridae. Revista del Museo Argentino 
de Ciencias Naturales "Bernardino Rivadavia", $8(3), 1-51$.

Bernasconi, I. (1963). Asteroideos argentinos. V. Familia Goniasteridae. Revista del Museo Argentino de Ciencias Naturales "Bernardino Rivadavia”, 9(1), 1-25.

Bernasconi, I. (1964). Asteroideos argentinos. V. Familia Ganeriidae. Revista del Museo Argentino de Ciencias Naturales “Bernardino Rivadavia”, 9(4), 59-89.

Brattström, H. \& Johanssen, A. (1983). Ecological and regional zoogeography of the marine benthic fauna. Report N. ${ }^{\circ} 49$ of the Lund University Chile Expedition 1948-49. Sarsia, 68, 289-339.

Camus, P. A. (2001). Biogeografía marina de Chile Continental. Revista Chilena de Historia Natural, 74, 587-617.

Castillo, J. (1968). Contribución al conocimiento de los ofiuroídeos chilenos. Gayana Zoología, 14, 1-63.

Clark, H. L. (1920). Asteroidea. Report 32 on the Scientific Results of the Expedition of the "Albatross" to the Tropical Pacific, 1904-1905. Mem. Mus. Comp. Zool. Harvard. Memoirs of the Museum of Comparative Zoology at Harvard College, 39(3), 69-114.

Clarke, K. R. \& Gorley, R. N. (2006). PRIMER v6: User Manual/Tutorial. PRIMER-E Ltd, Plymouth.

Clark, A. M. \& Downey, M.E. (1992). Starfishes of the Atlantic. London: Chapman \& Hall. 794 pp.

Crame, J. A. (1999). An evolutionary perspective on marine faunal connections between southernmost South America and Antarctica. Scientia Marina, 63(S1), 1-14.

Dahm, C. (1999). Ophiuroids (Echinodermata) of southern Chile and the Antarctic: taxonomy, biomass, diet and growth of dominant species. Scientia Marina, 63(S1), 427-432.

Darvill, C., Stokes C., Bentley, M., Evans, D. \& Lovell, H. (2016). Dynamics of former ice lobes of the southernmost Patagonian Ice Sheet based on a glacial land systems approach. Journal of Quaternary Science DOI: $10.1002 /$ jqs. 2890 .

Escribano, R., Fernández, M. \& Aranís, A. (2003). Physical-chemical processes and patterns of diversity of the Chilean eastern boundary pelagic and benthic marine ecosystems: an overview. Gayana (Concepción), 67(2), 190-205.

Fernández, M., Jaramillo, E., Marquet, P. A., Moreno, C. A., Navarrete, S. A., Ojeda, F. P. \& Vásquez, J. A. (2000). Diversity, dynamics and biogeography of Chilean benthic nearshore ecosystems: an overview and guidelines for conservation. Revista Chilena de Historia Natural, 73(4), 797-830.
González-Wevar, C. A., Hüne, M., Rosenfeld, S., Gérard, K., Mansilla, A. \& Poulin, E. (2016). Patrones de diversidad y estructura genética en especies antárticas y subantárticas de Nacella (Nacellidae). Anales Instituto Patagonia (Chile), 44(3), 49-64.

Griffiths, H., Danis, B. \& Clarke, A. (2011). Quantifying Antarctic marine biodiversity: the SCAR MarBin data portal. Deep Sea Research Part II: Tropical studies in Oceanography, 58(1), 18-29.

Gray, J. S. (2001). Antarctic marine benthic biodiversity in a world-wide latitudinal context. Polar Biology, 24(9), 633-641.

Gray, J. S. (2002). Species richness of marine soft sediments. Marine Ecology Progress Series, 244, 285-297.

Haussermann, V. (2006). Biodiversity of Chilean sea anemones (Cnidaria: Anthozoa): distribution patterns and zoogeographic implications, including new records for the fjord region. Investigaciones Marinas, $34,23-35$.

Hulton, N. R., Purves, R. S., McCulloch, R. D., Sugden, D. E. \& Bentley, M. J. (2002). The last glacial maximum and deglaciation in southern South America. Quaternary Science Reviews, 21(1), 233-241.

Hunter, R. L. \& K. M. Halanych. (2008). Evaluating connectivity in the brooding brittle star Astrotoma agassizii across the Drake Passage in the Southern Ocean. Journal of Heredity, 99(2), 13-148.

Kilian, R., Baeza, O., Steinke, T., Arevalo, M., Ríos, C. \& Schneider, C. (2007). Late Pleistocene to Holocene marine transgression and thermnohaline control of sediment transport in the western Magallanes fjord system of Chile $\left(53^{\circ} \mathrm{S}\right)$. Quaternary International, 161, 90-107.

Kilian R, \& Lamy, F. (2012). A review of Glacial and Holocene paleoclimate records from southernmost Patagonia (49-55 S). Quaternary Science Reviews, 53, 1-23.

Kilian, R., Baeza, O., Breuer, S., Ríos, F., Arz, H., Lamy, L., Wirtz, J., Baque, D., Korf, P., Kremer, K., Ríos, C., Mutschke, E., Michels, S., De Pohl-Holz, R., Arévalo, M., Wörner, G., Schneider, C. \& Casassa, G. (2013). Late Glacial and Holocene paleogeographical and paleoecological evolution of the Seno Skyring and Otway fjord systems in the Magellan region. Anales Instituto de la Patagonia, 41 (2), 5-26.

Lancellotti, D. A. \& J. A. Vásquez. (1999). Biogeographical patterns of benthic macroinvertebrates in the Southeastern Pacific littoral. Journal of Biogeography, 26, 1001-1006.

Larraín, A., Mutschke, E., Riveros, A. \& Solar, E. (1999). Preliminary report on Echinoidea and Asteroidea (Echinodermata) of the Joint Chilean-German-Italian 
Magellan Victor Hensen Campaign, 17 October-25 November 1994. Scientia Marina, 63(S1), 433-438.

Larraín, A. P. (1975). Los Equinoídeos Regulares Fósiles y Recientes de Chile. Gayana Zool. 35, 1-189.

López-Gappa, J. \& Sueiro, M. C. (2007). The subtidal macrobenthic assemblages of Bahía San Sebastián (Tierra del Fuego, Argentina). Polar Biology, 30: 679-687.

Madsen, F. J. (1956). Asteroidea, with a survey of the Asteroidea of the Chilean shelf. Repts. of the Lund University Chile Expedition 1948-1949 Lunds. Universitets Aarskrift N. F. Avd. 2, 52(2), 53 pp.

Munilla, T. \& Soler-Membrives, A. (2009). Check-list of the pycnogonids from Antarctic and sub-Antarctic waters: Zoogeographic implications. Antarctic Science, 21, 99-111.

Mutschke, E. \& Ríos, C. (2006). Spatial distribution and relative abundance of echinoderms from the strait of Magellan, Chile. Ciencia y Tecnología del Mar, 29, 91-102.

Mutschke, E. (2008). Macrobenthic biodiversity and community structure in austral Chilean channels and fjords. In: Silva, N. \& S. Palma (Eds.) Progress in the oceanographic knowledge of Chilean interior waters, from Puerto Mont to Cape Horn. pp 133-141. Comité Oceanográfico Nacional (CONA)-P. Universidad Católica de Valparaíso, Valparaíso.

Mutschke, E., Ríos, C., Aldea, C., Montiel, A., \& Silva, F. (2016). Biodiversidad marina en Magallanes: equinodermos del Pabellón de Colecciones Edmundo Pisano V. Anales del Instituto de la Patagonia, 44, 23-33.

Palma, S. \& Silva, N. (2004). Distribution of siphonophores, chaetognaths and euphausiids and oceanographic conditions in the fjords and channels of southern Chile. Deep-Sea Research II, 51, 513-535.

Palma, M., Quiroga, E., Gallardo, V. A., Arntz, W., Gerdes, D., Schneider, W. \& Hebbeln, D. (2005). Macrobenthic animal assemblages of the continental margin off Chile (22 to 42 S). Marine Biological Association of the United Kingdom. Journal of the Marine Biological Association of the United Kingdom, 85(2), 233.

Pantoja, S., Iriarte, J. L. \& Daneri, G. (2011). Oceanography of the Chilean Patagonia. Continental Shelf Research, 31(3), 149-153.

Pawson, D. L. (1966). The Echinoidea collected by the Royal Society of London Expedition to southern Chile, 1958-1959. Pacific Science, 20(2), 208-210.

Pawson, D. L. (1969). Holothuroidea from Chile. Report N. ${ }^{\circ} 46$ of the Lund University Chile Expedition 19481949. Sarsia, 38, 121-146.
Penchaszadeh, P. E., Bigatti, G. \& Miloslavich, P. (2004). Feeding of Pseudechinus magellanicus (Philippi, 1857) (Echinoidea:Temnopleuridae) in the SW Atlantic coast (Argentina). Ophelia, 58: 91-99.

Pinochet, P. \& Salinas, S. (1996). Estructura térmica y salina de canales y fiordos adyacentes a los campos de Hielo Sur. In: Comité Oceanográfico Nacional (ed.) Crucero de Investigación Científica Marina a los Fiordos y Canales adyacentes a Campos de Hielo Sur. pp. 15-25. Comité Oceanográfico Nacional, Chile.

Pérez-Ruzafa, A., Alvarado, J. J., Solís-Marín, F., ...(2013) Latin American echinoderm biodiversity and bigeography: patterns and affinities. In: Echinoderm research and diversity in Latin America, pp. 511-542. Springer Berlin Heidelberg.

Ríos, F., Kilian R. \& Mutschke, E. (2016). Chlorophyll-a thin layers in the Magellan fjord system: The role of the water column stratification. Continental Shelf Research, 124, 1-12.

Ríos, C., Mutschke, E. \& Montiel, A. (2013). Composition y estructura de la comunidad macrobentónicas en el sistema interior de canales y fiordos del extremo austral de Chile. Anales del Instituto de la Patagonia, $41,73-85$.

Ríos, C., Mutschke, E., Montiel, E. Gerdes, D. \& Arntz, W. (2005). Soft-bottom microbenthic faunal associations in the southern Chilean glacial fjord complex. Scientia Marina, 69(S2), 225-236.

Ríos, C. \& Mutschke, E. (1999). Community structure of intertidal boulder-cobble fields in the Straits of Magellan, Chile. Scientia Marina, 63(S1), 193-201.

Silva, N. \& Prego, R. (2002). Carbon and nitrogen spatial segregation and stoichiometry in the surface sediments of southern Chilean inlets (41-56 S). Estuarine, Coastal and Shelf Science, 55(5), 763-775.

Sladen, W. P. (1889). Asteroidea. Report of the Scientific Results of the Voyage of H.M.S. Challenger 1873-76. 30, 1-893.

Sievers, H. A. \& Silva, N. (2006). Masas de agua y circulación en los canales y fiordos australes. In N. Silva, \& S. Palma, (Eds.), Avances en el conocimiento oceanográfico de las aguas interiores chilenas, Puerto Montt a cabo de Hornos. Comité Oceanográfico Nacional-Pontificia Universidad Católica de Valparaíso, Valparaíso (pp. 53-58).

Valdovinos, C., Navarrete, S. A. \& Marquet, P. A. (2003). Mollusk species diversity in the Southeastern Pacific: why are there more species towards the pole?. Ecography, 26, 139-144.

Viviani, C. A. (1979). Ecografía del litoral chileno. Studies on Neotropical Fauna and Environment, 14, 65-123. 